\title{
LEARNING HOW TO WORK IN THE ARTS FIELD IN PORTUGAL: A BIOGRAPHICAL APPROACH TO THE MIGRANT ARTISTS' TRAJECTORIES*
}

\author{
L. Ferro ${ }^{1}$, P. Abrantes ${ }^{2}$, L. Veloso ${ }^{2}$, J. Teixeira Lopes ${ }^{1}$ \\ ${ }^{1}$ University of Porto \\ Via Panorâmica, 4150-564 Porto, Portugal \\ ${ }^{2}$ University Institute of Lisbon \\ Avenida das Forças Armadas, Edifício ISCTE, 1649-026 Lisboa, Portugal \\ (e-mail: 1ferro@letras.up.pt; pedro.abrantes@iscte-iul.pt; \\ luisa.veloso@iscte-iul.pt; jmteixeiralopes@gmail.com)
}

\begin{abstract}
The article considers the key dimensions of the life trajectories of the immigrant artists living in the Lisbon metropolitan area focusing on those related to the socialization process both in formal institutions and in a broader setting of informal learning. The authors conducted a sociological analysis of 20 biographical interviews with a heterogeneous set of individuals, including musicians, dancers and plastic artists. These interviews were a part of the research project on the social trajectories of migrant artists from the non-European Union countries living in Portugal. The results of the analysis show that formal and informal learning together with the migrant experience are intertwined and constitute the key factor in the configuration of migrant trajectories. There is often a mobility pattern across art styles, which makes differences between formal and informal circumstances in the life trajectories of migrant artists evident. Migration has a strong impact on the artistic work; this impact affects different areas of biographical experience: contact with the Portuguese culture, development of ethnic references, and participation in transnational art movements. The condition of immigrant artists generally implies a long trajectory of artistic training, including significant experiences of formal and informal learning in multiple social contexts throughout the life course. For those dedicated to the new transnational urban cultures (hip hop, graffiti, etc.), informal learning is the most important element. For those engaged in the traditional arts, the attendance of lengthy artistic programs seems to be a fundamental prerequisite for training and recognition. Together with the long and significant artists' investments in their education, the sociological study also revealed the great vulnerability (and precariousness) of their life trajectories, and the lack of structures supporting their access to the labor market.
\end{abstract}

Key words: migration; artists; biographical trajectories; formal education; informal education; Portugal; non-EU countries immigrants

The social-economic conditions, and learning and professional trajectories of migrant artists have been a rare object of sociological study. Arts are a realm of human practice and experience in which the mediation of cultural production and meanings takes place par excellence. As the world faces rapid changes and important conflicts considering cultural differences, it is necessary to focus on migrant artists to understand their experiences and positions in the field of culture and arts.

* (C) L. Ferro, P. Abrantes, L. Veloso, J. Teixeira Lopes, 2018. 
The article presents the results of the study of immigrant artists living and working in Portugal ${ }^{1}$. The project combined an extensive approach to the artistic and cultural practices of immigrants in Portugal, an ethnographic study of two contexts of these practices, and an analysis of the life trajectories of 20 immigrant artists living in the Lisbon metropolitan area. This biographical approach is based on the quantitative and ethnographic studies and contributes to our understanding of the current situation of immigrant artists and of the connections between this situation and the artists' socialcultural origins, different life experiences and prospects for the future. Certainly, various dimensions of the respondents' life courses could be considered for the biographical interview allows to analyze a wide range of issues. In this article, two main reasons determined our focus on formal and informal learning. On the one hand, little is known about this topic in the international tradition. On the other hand, the data collected during our fieldwork help us to better understand some common-sense notions, such as those that associate the artistic practices of immigrants with spontaneous and creative profiles of host societies, especially when coming from Africa and Latin America, and contrast with experiences more focused on education and work in the European countries. Such public images contribute to the legitimate forms of discrimination and exploitation together with the public policies' lack of attention to these migrant groups.

To understand the diverse ways of integration of immigrant artists in new societies, we need to analyze their learning patterns as a combination of formal learning, informal learning and migrant experiences.

\section{MIGRANT AND LEARNING TRAJECTORIES: A THEORETICAL FRAMEWORK}

The relation between artistic activities and migratory processes has only recently became an international research topic. According to DiMaggio and FernándezKeller [15], the scarcity of previous studies in the USA is especially surprising given the massive numbers of migration and the importance of arts to immigrant communities as providing them with comfort, tools to interpret personal experiences, labor integration, social mobility, political participation, strong internal solidarities, and (re)construction of identity in the host society. In Europe, Martinello [25] stresses the lack of research of the participation of immigrants in artistic activities as contrasting the complexity and relevance of the subject, and suggests several topics for future research, such as cultural dynamics, social relations, urban policies, political participation, and local economies.

In cultural studies, the experience of individuals in various contexts is considered as stimulating original artistic work and leading to hybrid creations often as a way of claiming a cultural citizenship under the political and economic marginalization [11].

1 The research project 'The work of art and the art of work - training and labor creative circuits of integration of migrant artists in Portugal' was supported by the European Commission/Portuguese High Commissioner for Migrations. We thank Otávio Raposo, a coordinator of the project together with Lígia Ferro, and the team of researcher (Pedro Varela, Ricardo Bento, and Tiago Caeiro) for their support in recruiting respondents and conducting the interviews. 
The studies of the economic dimension of migration prove the growing mobilization of transnational social networks in migratory processes, frequently these are familybased networks creating 'transnational entrepreneurs' [29]. The difficulties of immigrants to access more conventional, secure and institutionalized paths of integration and upward social mobility make entrepreneurship an attractive way especially in creative activities which are risky and labor intensive [21].

Other studies stress the obstacles faced by immigrants in artistic fields, especially when they aim to professionalize their creative work and earn a living from it. Borén and Young [7] show that artists in Stockholm are characterized by high mobility patterns but also a strong local embeddedness. They do not migrate more often than other professional groups and, regardless of the eminently cosmopolitan rhetoric, they do mainly due to their working and living conditions, often to 'expand' their market. As work opportunities frequently depend on 'tacit knowledge' and informal networks, early access to the native artistic circuit is a factor contributing to success especially in periods of economic downturn. Institutions, in particular the most prestigious educational ones, are powerful agents regulating the endogamous reproduction of the field and the exclusion of immigrant artists. Challenges to artists' migration are especially serious in adulthood due to the pursuit of economic autonomy and family wealth; mobility is very intense in the artists' youth as determined by learning and experiments, it increases again in the last period of their careers.

Bergsgard and Vassenden [5] explain the low number of artists from ethnic minorities in Norway by describing the arts as a highly institutionalized field in which particular social and cultural capitals gained in the local context are required to access the (few) available places. Although independent and commercial projects possess some openness, the authors emphasize the benefits of the privileged social class background and study in the most prestigious arts schools when employment in the fields of theatre and dance is concerned. Hence, the merit of immigrant artists is recognized mainly when they practice a style which is considered exotic, and theatre directors or choreographers look for someone with those specific features. Immigrant families are likely to steer their children to engineering or management as more open and offering more chances for upward social mobility. To some extent, this resonates the process identified by Certeau [12] within the ethnologization of popular cultures as a harmless reminder of authenticity in the institutional frameworks. Indeed, the city marketing and branding integrate 'ethnic' and 'exotic' in their strategies to promote the representation of the city as celebrating the depoliticized cultural differences in the public sphere [20]. Thus, Bourdieu [9] defines arts as an arena of power conflicts and relations, and the position of each actor in a given 'artistic field' depends on his life trajectory. Economic, cultural, political, symbolic and social capitals are interchanged along this trajectory to develop a particular way of thinking, feeling and acting (habitus).

A study conducted in Portugal [26] shows that many artists migrated to Portugal during last three decades, especially from other Portuguese-speaking countries (e.g. Brazil, Angola or Mozambique), and they are employed mainly in non-artistic areas, often in low-skilled sectors. Yet, in many cases, personal competences were invested in non-creative 'semi-artistic' occupations in education, (re)production or commerciali- 
zation of arts. The arts provide also a way to get a non-artistic work, especially within 'ethnic markets' [15]. It seems useful to use the Becker's concept of 'art worlds' as communities organized around artistic production and regulated by a number of specific standards of many agents engaged in different activities [3].

The studies of migration in Portugal revealed a partial convergence of the country with European and North American patterns together with some national specifics such as concentration of immigrants in the Lisbon metropolitan area and in low-skilled jobs despite their educational levels being similar to those of the Portuguese [28]. The migrants' labor integration is almost always subject to the market logics and often informal with little regulation by the state. According to Oliveira and Gomes [27], the share of immigrant population formally engaged in 'artistic, entertainment, sports and leisure activities' is low $(1,1 \%)$, but higher than the share of the native population in the same category $(0,8 \%)$.

While various dimensions of social life are relevant to this debate, we shall consider the learning processes of immigrant artists paying special attention to the interconnection between trajectories of formal education, informal learning and the migratory experience. We use the concept 'socialization' to understand the overlap of these various contexts in the way individuals acquire and develop knowledge, techniques, values, dispositions and identities. Being dependent on the family environment in the childhood, primary socialization processes play a key role in the acquisition of deep and lasting structures determining the ways of thinking, feeling and acting especially in cultural practices and consumption $[4 ; 8 ; 31]$. With regard to migratory processes, local practices and emotional bonds proved to constitute the prime mechanisms of developing competences and values, including the necessary resistance to discrimination and delinquency [32]. However, the role of primary socialization can be questioned in the light of recent studies which underline the key impact of educational pathways in the development of cultural patterns, acquisition of social capital and (re)definition of life trajectories $[6 ; 14 ; 23]$. Cultural practices and consumption themselves, especially among youngsters, are important mechanisms of (re)socialization [30].

Socialization is shaped by multiple contexts of interaction, various stages of life, internal conflicts and turning points in the biographical trajectory; thus, the transfer of experiences, unity of self and biographical consistency become challenges for personal existence $[2 ; 16 ; 18 ; 22]$. It is though remarkable how life histories can make up a stable stock of knowledge and expectations even under the dramatic social change [19]. We believe that the recognition of artists in the contemporary societies in Europe depends on a long-term artistic training starting in the country of origin and later acknowledged and continued in formal and informal learning in host society, and also on the general migratory experience.

The article is based on biographical interviews conducted with 20 immigrant artists living in the Lisbon metropolitan area. These 'cases' represent the contexts of our ethnographic research and institutions that support immigrants and arts. In short, the intensive and extensive work within our broader research project allowed us to identify the following indicators to ensure some social and cultural diversity: gender, type of art, 
degree of professionalization in arts, nationality, age, and duration of stay in Portugal. We interviewed immigrant artists who were born in countries outside the European Union, were migrants, had and had not a previous artistic experience in their home country. We also sought heterogeneity with regard to the types of art: we interviewed six people dedicated to dance, six - to music, one - to both dance and theatre, one currently working in cinema and video (as a director and assistant director) as well as music, five plastic artists, two theatre professionals who work mainly as playwrights (one is also a theatre director and teacher in this field) and one writer. Though we tried to find women immigrant artists, only a third of the respondents is female. Reaching women was difficult, either because they were less present in the settings or less often indicated by the institutions consulted during the research. In general women are underrepresented among immigrant artists in Portugal. Considering the professionalization, we managed to get a balanced set of interviewees: ten earn living by arts while other ten are semi-professional artists combining artistic activities with other types of work. Interviews took from 1 to 3 hours and focused on artistic pathways, migration experiences, living conditions and life prospects.

\section{MIGRANT TRAJECTORIES AND LEARNING PROCESSES}

Our analysis is focused on three issues: learning processes of immigrant artists in formal educational settings, informal learning, and migratory experience as a key factor of migrants' life trajectories and identities.

\section{Formal education}

Most of our twenty respondents have a long record of formal education, including the university level, which is not typical for the social and educational profile of immigrants in Portugal [27] and contrasts the stereotype that artistic careers facilitate the labor integration of immigrants of low educational levels [15]. Several of artists arrived in Portugal with a bachelor degree, others came to enroll in higher education. This is especially common among artists from Portuguese-speaking countries in Africa: their knowledge of language and culture offers them - or so they expect - access to the European artistic market. This is typical for artists both from affluent class backgrounds and for those who received a study grant. Having migrated with some reserve funds, these artists report experiences of precariousness in Portugal: "I followed the vocational track. I was recognized [in São Tomé e Principe] at a very young age by both the Alliance Française, which promoted and paid attention to young people with some talent, and by the Portuguese Cultural Centre which made an excellent work in the $1980 \mathrm{~s}$ and 1990s, meaning there was an investment so that I got the study grant and... came to study Fine Arts in Portugal. I had two options then because I was given two grants one to go to France, and one to come to Portugal. I eventually chose Portugal and this is where I did my studies. I came first to an artistic school, where I completed my secondary education... Afterwards I went to the Faculty of Fine Arts in Lisbon. I began by studying Painting, then changed my mind, moved to the Sculpture and that's what I graduated in" (plastic artist, Santomean, man, 43 years old). 
The relevance of experiences at school for getting people into artistic practice is significant. Despite their common references to an inborn talent for the arts (as well as explanations based on divine gifts), many respondents explain their access of the world of arts by the influence of their school (primary education) or at least of some teachers who encouraged them toward an artistic career. Cross-curricular leisure activities in these educational institutions are often mentioned as opportunities to develop artistic skills. In other cases, courses in art academies or cultural centers in the early age are mentioned as main channels of initial (and peripheral) participation in the arts for the talent was detected and oriented to specialized training and institutional funding.

The diversity of art forms in these experiences and initiatives vis-à-vis the professional development in the adult age is impressive and proves close ties between different arts and artistic dispositions (for two men an important relation with the intense sports practice in childhood is also evident). This is illustrated by the dancers who associate their artistic success with the early contact with poetry, actors who remember their childhood passion for painting, and plastic artists with an intense music practice in their childhood: "[At the age of five] I was walking past a shop window and I asked my father: 'I want one of those instruments!'. And he gave me the guitar. So, I was given the guitar for my anniversary and I didn't know how to play it. I would stay at home making and making noises, I was hitting the guitar any way I could, up to a moment when my father said... 'I'm going to break that shit because I can't stand the noise anymore!'. And my mother told him: 'Look, this is a gift you offered the boy, the boy can't play it, you must take him to a school'....Therefore, I went to the school to learn play the guitar when I was five years old. And the teacher was a plastic artist who taught piano as well as sculpture and drawing. ...She was a teacher at the school I went to, it was a private school, we had artistic training from kindergarten. ...And she taught me arts at school and music lessons at her home. ...I was so eager about that lesson, the moment with that teacher. I liked her a lot, and interestingly I took advantage of the situation because I had guitar lessons twice a week at her home, so I talked to her about more stuff, she had a lot of things at home, her home was like a mini-gallery or something like that for me at the time, and I was delighted to see all of that..." (plastic artist, Brazilian, man, 33 years old).

Furthermore, higher education institutions are crucial for the access to the artistic field not only through formally establishing legitimate standards of cultural production and training students for the development of dispositions relevant to the standards, but also due to the strong networks of professors and other gatekeepers of the artistic field, who provide a limited number of students with channels to participate in professional artistic projects [5; 9]. Interestingly, this is the case of higher education institutions in Portugal even for plastic artists who develop styles with strong references to the cultures of their home countries. However, for other immigrant artists, the educational trajectory was short and riddled with failure: some never attended artistic institutions, practiced self-teaching, used family or community training options. In these cases, school represents at best a place to access some urban music and art movements through youth networks developed by peers [30]. 
Besides, the fact that many immigrant artists have a college degree does not mean that this was always in an artistic field or completed successfully. While some respondents have an artistic trajectory clearly associated with their educational pathways, including art courses at university, others had university courses in different fields, some did not finish them precisely for being engaged in the artistic activities. Thus, educational trajectories are often winding and intermittent, and some conflicts with educational institutions are reported together with an artistic 'ethos' of authenticity and partial institutional marginality [9]: "[University] was a great experience for me. ...But I wasn't able to focus on it at that time... because I decided to stop it for a year. People told me then: 'If you stop for a year, you'll stop forever!' Absolutely true. ... [At the university] I learned that there are a lot of liars, a lot of bastards, but also a lot of people who aren't like that...I'm not bitter about it, but I was very naive at that time and I thought that people always presented pieces created by themselves, either with or without help, but not some shit they had just put their name on. Or when you go and ask for help, and people tell you: 'Oh, I can't help you!'. I found that very scary”' (plastic artist, Santomean, man, 41 years old).

The relation between education and position in the artistic field is far from linear whether we look at professionalization, income or status. Among the immigrants with degrees in arts, some undertake artistic activities on a full-time basis and get income from, others combine them with paid non-artistic activities. The same diversity is found among those with other university degrees or low educational levels. However, immigrants with a university degree are able to combine their artistic activities with non-artistic activities that are more gratifying in economic, cultural or social respects. On the contrary, those with low educational levels who do not succeed in earning a living solely from artistic or semi-artistic work are bound to tough, routine, temporary and badly paid jobs, which in turn becomes a major obstacle to their participation in the arts.

The artists interviewed make a substantial use of free courses, workshops and internships to update knowledge or specialize in particular subjects. This is especially the case of those who already have a university degree. Many of the respondents say that short-term training programs were a 'turning point' in their biographies [6] providing them with the access to the artistic field in Portugal after they had begun their artistic career in other countries. In some cases, this was indeed the reason why they came to Portugal; only later they decide to stay in the country due to their engagement in longterm projects. In other cases, training was not the reason to migrate but a way to seek integration in a new setting. These experiences not only generated ties to teachers and colleagues who were better positioned in the field (later leading to important invitations and projects), but also allowed for their better adaptation to the Portuguese context. In some trajectories, educational and employment experiences were intertwined making it difficult to understand where one ends and the other begins: "I've always been a curious person, eager to learn... also with respect to antiquities, which I like very much. In São Paulo we did some restoration works and things like that. Well, when I arrived here I was fascinated because there are... wonderful courses, including one of the best in Europe in that particular subject... I started with the most basic one, it was 
woodworks... and then I did painting in the Ricardo Espirito Santo Academy, that's where I got my degree. And I study whenever I can. I do it because this is a field in which it is impossible to say: 'I'm done with learning, I've learned everything'. No, that's impossible in this field.." (plastic artist and restorer, Brazilian, woman, 56 years old).

According to our interviews, early artistic initiation in the home country and education in Portugal are both crucial for learning and integration in the arts field, even if, in many cases, there is not a clear continuity between them regarding the type of art or the style. Migration poses obstacles to the continuity of an artistic trajectory but also opportunities to engage in new areas of arts training. Only a capoeira practitioner from Brazil and a dancer from the USA completed their specialized training in their home country and continued their work in Portugal without any advanced training in the country. The interviews suggest a substantial barrier in the local cultural field with educational institutions playing a gatekeeping function similar to other countries of Europe [5; 7].

\section{Informal learning}

Although many respondents believe that their artistic activity is determined by the 'gift' they possess (an inborn capacity for artistic practice) they also acknowledge informal learning as a key to their personal and professional trajectory. The ties established with some family members or friends connected with arts are highly valued by social actors who recognize the great importance of these ties in their artistic trajectories.

Informal learning is important especially for musicians engaged in hip hop, in particular concerning their joint activities with friends in the neighborhoods. These cases prove the previous findings in other countries emphasizing the prominent role played by informal learning in the hip hop culture as enhancing a creative linguistic learning, increase of reflexivity and development of alternative identities [1]. One of our interviewees remembers that socialization among people of various generations on the street enabled him to learn about musical performance and production, thus, exposing the role of the street as a privileged setting for constructing networks [13]: "Man, when you're out on the street you have a view of everything! On the streets you can be a criminal, you can be a very smart guy... you see what I mean?... and incorporate the good things about the street life. The street is not only about bad things as people think: 'Oh! The street...'. The street has good things too! If you're really good at looking into things, you can see that the street has good things. Sometimes I even hung around old guys who were just playing music there. I'd go there and see how that stuff was made, how a chord is made. I mean, I don't play the guitar but I would watch how they put their hands, like this, you see? And so I could get that beautiful sound out of the instrument, you know what I mean? (musician and video producer, Angolan, man, 31 years old).

At several moments during his interview, this respondent stresses the relevance of various rappers in his life trajectory because of the learning pathways shown by them especially in singing and music and video production. Without any formal artistic education, he ascribes a very important role to this informal learning with friends, first in the studio and then in other places of the neighborhood; among his friends, some 
had a close connection with the hip hop culture, others worked with different musical genres. He argues that some informal artistic settings and activities can enhance the artistic learning of young people, while also offering lifestyle alternatives to illegal and criminal activities in which many young people from poorer backgrounds are likely to get involved.

The artistic learning of our respondents in the hip hop culture covers various art forms leading to rather hybrid practices. All of the rappers are currently engaged or were previously engaged in other artistic activities besides music — dance, painting, sculpture, or video. In the trajectories of plastic artists, learning and contact with other art forms, such as music and theatre, are also important. These artistic expressions were introduced to them by friends or relatives. For most of the interviewees in this group, the family plays an important role as a source of the very first artistic stimuli during childhood; relatives somehow connected with arts were crucial in their trajectory. One of our respondents explains how his work was strongly influenced by intergenerational exchange and popular culture, mainly due to his grandfather: "I think my life course has been very influenced by arts, and especially by popular wisdom and arts. And, in this respect, my grandfather has always been a key figure, because much of the information about the Santomean culture that I was able to organize in a more systematized manner comes from the oral tradition. The context... I lived in a poor neighborhood where the context for life and learning was dialogue, storytelling among the youth, children and elderly. I spent a lot of time among the elderly, and I was shaped by that passage of information, even an anthropological sort of information, and I learned a lot from it. So the construction of an artistic discourse and life paralleled this learning of popular tradition, and this is reflected in my work" (plastic artist, Santomean, man, 45 years old).

Many of immigrant artists were left without their family networks when they migrated. Therefore, the bonds of friendship that they are able to develop in Portugal, typically with other artists, can play a very important role not only in their learning and integration in the artistic field, but also in personal life and emotional fulfilment. Self-education is also highly relevant to these artists. Many of them describe how Internet and other means of communication such as radio and television (especially for musicians) have been and still are a major source of learning. One of the respondents repeatedly mentions that tutorial lessons available on the Internet are instructive, inspiring and technically innovative, enabling him to learn other ways of painting and sculpturing. Another respondent, an older singer, mentioned that Bollywood films inspired her musical activity while she was in Mozambique. She also emphasizes the importance of self-education together with the influence of a neighbor who taught her a number of things and encouraged her to sing: "There was a gentleman with a huge influence on me, and still today; it's Mr. Jassu. I sang so much that my voice was hoarse at the end of the day. And he said, go on, go on, and he encouraged me a lot. Even later, already in Portugal, he would say: 'Now you're going to sing in devanagari', which is another Hindi language, and I did it. Afterwards I learned how to breathe and sing without getting hoarse, but that was through intuition, I learned it by myself. But I always say that Mr. Jassu, that gentleman, he was my mentor. When I was about to leave Mozambique, he told me: 'You'll go far',' (singer, Mozambican, woman, 50 years old). 


\section{Migration experiences}

We conclude our study of formal and informal learning with an approach to migratory movements emphasizing how they influenced the artistic practices. The analysis of the interviews makes us consider two main dimensions: a) how the trajectory is 'inherited', i.e. determined by the respondent's migration to Portugal with her or his parents and not being a result of self-planning; or 'constructed' by the decision of the respondent as an adult; b) to what extent artistic practices are or are not related to practices rooted in cultural traditions of the respondent's home country.

The 'inherited' migratory trajectories prevail among respondents who migrated to Portugal with their parents. In these cases, migration was forced by the political situation in the former Portuguese colonies before or after the coup d'état in 1974, and by some family ties with Portuguese nations. Only one of our respondents moved successively between several countries, which he considers an important element in his learning trajectory for it enabled him to broaden his horizons and get acquainted with many people and other forms of painting. While some of respondents are unable to earn a living solely by arts, arts nevertheless retain a central role in their personal and professional lives. Several respondents refer more or less directly to the artistic practices associated with specific urban settings and cultural references from their home country. This is especially the case among those devoted to the hip hop movement. The rap, originally unrelated with the culture of their home country, is nowadays a musical genre of various social strata. It is also an artistic practice with a strong impact on populations of deprivileged urban areas especially the youth, some of them with immigrant origins. Thus, many of them use the rap to reflect upon their everyday experience and mobilize ethnic identity. There is an interconnection between learning through the migratory process and the consolidation and transformation of an artistic practice such as rap in the particular urban setting where immigrant artists live and perform: "I feel I'm a citizen of the world... I'm Angolan, I was born in Angola, I know where I come from. Well, I grew up in Portugal and I can't say I'm Portuguese either. And I have Cape Verdean roots. I'm not going to mess around with my head about it, man. I belong to the world; I mean, if one day I'm living in Italy, I'll feel I belong to the world, I won't say I'm Italian, Angolan or anything else, you see what I mean? (music and video producer, Angolan, man, 31 years old).

A different relation with Portugal and the migratory trajectory is evident among the respondents who moved to Portugal by their own decision rather than due to their older relatives — this is a 'constructed' trajectory. For instance, some artists moved to Portugal at a later moment in life within an international trajectory already shaped by artistic practices, or with a plan of getting higher education. These respondents carry out professional or semi-professional activities with considerable visibility, for instance writing theatre plays, working with a nongovernmental organization and thus promoting artists of a given nationality, directing stage shows, or teaching. The mobility of these respondents includes visits to their home country, which enables them to learn from the simultaneous contacts with two countries and the reinforcement of their connection with the culture of their home country. Although their artistic practices are strongly 
linked to their culture of origin, some respondents consider that their work can be presented in numerous international contexts: "Art unites Greeks and Trojans, Jews, Muslims, Palestinians... art has the power to be neutral, it does not recognize differences of color, race, or purchasing power. Art is the only thing in the world that always values people regardless of ethnicity or nationality. Art has this natural role of gathering and uniting, according to my mind and my experience" (dancer and actor, Bangladeshi, man, 28 years old).

The circulation between cultures, namely translating into forms of 'mestizo mind' thinking [17], is sometimes associated with difficulties of acceptance in Portugal. One of the respondents says that her artistic practice is a 'mixture of three cultures' Portuguese, Indian and Mozambican — and described the obstacles that she encountered as an artist. These include the 'harsh' manner in which she was treated in the auditions for the TV program, when one of the members of the jury told her that Hindi was not an appropriate language for that show in Portugal: "He told me... 'That's not the kind of music people sing around here. If only you had brought a song in English, or in Portuguese! But coming up here with a song in Hindi, that's not suitable here, that's for India.' And I thought to myself: this guy is telling me to go back home. I was sad because I think he completely downplayed the Indian language. Maybe if it was Chinese he'd have given it more value. I don't know if it's ignorance. I think that's more the case. But it was somewhat harsh" (singer, Mozambican, woman, 50 years old). The acceptance of this respondent's culture in Portugal is not easy, and this is perhaps why she also tries to develop artistic practices with cultural references which are markedly Portuguese.

Other respondents migrated to Portugal by their own decision but their trajectories rely on artistic practices associated with various forms of contemporary global culture and not so much with the culture of their home country. Their trajectories are characterized by participation in a wide range of projects and difficulties in obtaining economic stability; as put by one of the respondents, there are always 'zones of uncertainty' and 'even opening a bank account is difficult'. Another respondent describes how she was engaged in various projects and countries over last years due to invitations to take part in collective projects. She intends to apply for the Portuguese nationality because she wants to stay in the country: "I got very used to life here, and it's different, much different from where I come from concerning security and walking around and things like that. I love my land, I love its culture and I think it's very inspiring, and artistic works there are of a very different level than here, and the approach is also different from the European. But I don't know... I really fell in love with Portugal. I made the choice of staying here. When I came in 2011, I had three work opportunities, in practice I could choose between settling down in Portugal or settling down in London" (dancer, Brazilian, woman, 26 years old).

This quote helps us understand the situation of these artists and the central role of mobility, either willful or not, in their learning and socialization trajectories especially associated with working on a project-basis, an increasingly common feature for some economic and professional activities [24]. The migratory experience is certainly a key in the learning trajectories of the respondents and - in different ways - shapes 
learning as well as the development and configuration of artistic practices. Connected either with the migratory trajectory of the family or with the pursuit of formal education and work in Portugal (or Europe), the migratory trajectory goes hand in hand with a trajectory of formal and/or informal learning started in the country of origin. Artists use multiple ways of bonding with or drawing away from what can be called traditional/ popular cultures of their home country. In some cases, this relation is clear and outspoken. In others, home country cultures are explored as 'exotic' cultures in Europe within the so-called multiculturalist movements. In third cases, they are intertwined with urban artistic practices which are widely recognized and integrated in the artistic worlds. Still, the lack of association with home country cultures prevails among artists who identify — and got relevant formal and/or informal learning — with artistic practices that are transnational and closer to particular artistic trends than to national or ethnic cultures.

$* * *$

Despite the prevailing association of artistic vocation with a personal gift (often of divine origin), the immigrant artists tend to imply a long trajectory of artistic training starting at an early age (in various art forms), including significant experiences of formal and informal learning in multiple social contexts. There is a striking difference between our twenty respondents in this respect: for those dedicated to new transnational urban cultures (hip hop, graffiti, etc.), informal learning is the most important element; in more classical art forms, the lengthy artistic programs seem to be a fundamental prerequisite for training and recognition in the field.

The relation between migratory processes and careers of individuals as artists varies considerably. In many cases, initiation in the arts started in the home country and migration is a result of the desire to attend specialized training in the field or enlarge artistic and life experiences (determinant for the consolidation of dispositions and identities recognized in the artistic field). In other cases, migration at an early age, generally when accompanying older relatives, preceded the artistic trajectory, which does not mean that the cultural background is not used in the creative work. In any case, formal learning experiences in Portugal (courses, workshops, internships, etc.) is of a great their importance for our respondents to access the local artistic circuits. This happens not only through the development of techniques, styles and dispositions valued in the Portuguese context - including development of markedly 'ethnic' styles - but also through integration in a local network sometimes also characterized by ethnic divisions, which is nevertheless fundamental for the migrants' recognition as artists.

Together with a long investment in education, our study also revealed the great vulnerability (and precariousness) of the migrant artists' trajectories and the lack of structures that support the access to the labor market. This often makes artists combine their artistic activity with other activities providing a more secure income, or to move to places with prospects for earning more from their artistic work even if on a temporary basis. 


\section{REFERENCES}

[1] Aliagas C, Férnandez J.-A., Llonch P. Rapping in Catalan in class and the empowerment of the learner. Language, Culture and Curriculum. 2016; 9 (1): 73-92.

[2] Beck U., Beck-Gernsheim E. Individualization. London: Sage; 2002.

[3] Becker H. Art Worlds. Berkeley: University of California Press; 1982.

[4] Berger P., Luckmann T. The Social Construction of Reality. Garden City: Anchor Books; 1966.

[5] Bergsgard N., Vassenden A. Outsiders? A sociological study of Norwegian artists with minority background. International Journal of Cultural Policy. 2015; 21 (3): 309-325.

[6] Biesta G., Field J., Hodkinson P., Macleod F., Goodson I. Improving Learning Through the Lifecourse. London: Routledge; 2011.

[7] Borén T., Young C. The migration dynamics of the 'creative class': Evidence from a study of artists in Stockholm. Annals of the Association of American Geographers. 2013; 103 (1): $195-210$.

[8] Bourdieu P. Distinction: A Social Critique of the Judgment of Taste. Harvard: HAP; 1984.

[9] Bourdieu P. The Rules of Art: Genesis and Structure of the Literary Field. Stanford: Stanford University Press; 1995.

[10] Caetano A. Personal reflexivity and biography: methodological challenges and strategies. International Journal of Social Research Methodology. 2015; 18 (2): 227-242.

[11] Canclini N. Hybrid Cultures: Strategies for Entering and Leaving Modernity. Minneapolis: University of Minnesota Press; 2005.

[12] Certeau M. L'Invention du Quotidien. Paris: Gallimard; 1990.

[13] Cordeiro G., Vidal F. A Rua: Espaço, Tempo, Sociabilidade [The Street: Space, Time, and Sociability]. Lisboa: Horizonte; 2008 (In Portug.).

[14] Darmon M. La Socialisation [Socialization]. Paris: Armand Colin; 2007 (In French).

[15] DiMaggio P., Fernández-Keller P. Art in the Lives of Immigrant Communities in the United States. New Brunswick: Rutgers; 2010.

[16] Dubar C. La Socialisation: Construction des identités sociales et professionnelles [Socialisation: Construction of Social and Professional Identities]. Paris: Armand Collin; 2000 (In French).

[17] Gruzinski S. La Pensée Métisse [The Mestizo Thought]. Paris: Fayard; 1999 (In French).

[18] Hackstaff K., Kupferberg F., Negronie C. Biography and Turning Points in Europe and America. Bristol: Policy Press; 2012.

[19] Hoerning E., Alheit P. Biographical socialization. Current Sociology. 1995; 43 (2): 101—114.

[20] Kiliç Z., Petzen J. The culture of multiculturalism and racialized art. German Politics and Society. 2013; 31 (2): 49-65.

[21] Kupferberg F. The established and the newcomers: what makes immigrant and women entrepreneurs so special? International Review of Sociology. 2003; 13 (1): 89-104.

[22] Lahire B. Portraits sociologiques: Dispositions et variations individuelles [Sociological Portraits: Dispositions and Individual Variations]. Paris: Nathan; 2002 (In French).

[23] Levinson B., Foley D., Holland D. The Cultural Production of the Educated Person: Critical Ethnographies of Schooling and Local Practice. New York: State University of the New York Press; 1996.

[24] Lundin R. et al. Managing and Working in Project Society: Institutional Challenges of Temporary Organizations. Cambridge: Cambridge University Press; 2015.

[25] Martinello M. Immigrants, ethnicized minorities and the arts: A relatively neglected research area. Ethnic and Racial Studies. 2015; 38 (8): 1229-1235.

[26] Nico M. et al. Licença para Criar: Imigrantes nas Artes em Portugal [License to Create: Immigrants in Arts in Portugal]. Lisboa: ACIDI; 2007 (In Portug.).

[27] Oliveira C., Gomes N. Monitorizar a Integração de Imigrantes em Portugal [Monitoring Immigrant Integration in Portugal]. Lisboa: ACM; 2014 (In Portug.).

[28] Peixoto J. How the global recession has impacted immigrant employment: the Portuguese case. Papademetriou D. et al. (Eds.) Migration and the Great Recession: The Transatlantic Experience. Washington: Migration Policy Institute; 2011. Pp. 106-125. 
[29] Portes A., Guarnizo L., Haller W. Transnational entrepreneurs: An alternative form of immigrant economic adaptation. American Sociological Review. 2002; 67 (2): 278-298.

[30] Rácz J., Zétényi Z. Rock concerts in Hungary in the 1980s. International Sociology. 1994; 9 (1): $43-53$.

[31] Scherger S., Savage M. Cultural transmission, educational attainment and social mobility. Sociological Review. 2010; 58 (2): 406-428.

[32] Soehl T., Waldinger R. Inheriting the homeland? Intergenerational transmission of cross-border ties in migrant families. American Journal of Sociology. 2012; 118 (3): 778 — 813.

DOI: $10.22363 / 2313-2272-2018-18-3-507-520$

\title{
ОСВОЕНИЕ ПРИНЦИПОВ РАБОТЫ В СФЕРЕ ИСКУССТВ В ПОРТУГАЛИИ: БИОГРАФИЧЕСКИЙ ПОДХОД К ИССЛЕДОВАНИЮ ЖИЗНЕННЫХ ТРАЕКТОРИЙ МИГРАНТОВ*
}

\author{
Л. Ферро ${ }^{1}$, П. Абрантеш², Л. Велосо ${ }^{2}$, \\ Ж. Тейшера Лопеш ${ }^{1}$ \\ ${ }^{1}$ Университет Порту \\ Виа Панорамика, 4150-564, Порту, Португалия \\ ${ }^{2}$ Лиссабонский университет \\ Авенида дас Форсас Армадас, 1649-026, Лиссабон, Португалия \\ (e-mail: 1ferro@letras.up.pt; pedro.abrantes@iscte-iul.pt; \\ luisa.veloso@iscte-iul.pt; jmteixeiralopes@gmail.com)
}

В статье рассмотрены основные измерения жизненных траекторий мигрантов, занятых в сфере искусств и проживающих в Лиссабоне и его окрестностях, и акцент сделан на особенностях их социализации одновременно в формальных институтах и широком контексте практик неформального обучения. Авторы провели социологический анализ 20 биографических интервью с разными информантами, включая музыкантов, танцоров и скульпторов. Эти интервью были частью исследования социальных траекторий мигрантов из стран, не входящих в Европейский Союз, которые заняты в сфере искусств и живут в Португалии. Результаты проекта показали, что формальное и неформальное обучение тесно переплетены с миграционным опытом и, тем самым, являются основным фактором, определяющим конфигурацию жизненных траекторий мигрантов. Для них характерны перемещения между стилями художественной деятельности, которые порождают очевидные различия между формальными и неформальными обстоятельствами биографий. Миграция серьезнейшим образом влияет на творчество и, тем самым, на биографический опыт: важное значение имеют знакомство с португальской культурой, развитие этнических связей и участие в международных художественных движениях. Как правило, иммигранты с художественным опытом и амбициями проходят через длительный период подготовки, сочетающий разные варианты формального и неформального обучения в множественных социальных контекстах. Для тех, кто привержен новым международным городским культурам (хип-хоп, граффити и пр.), наибольшее значение имеет неформальное обучение. Для тех, кто вовлечен в сферу более традиционных искусств, участие в длительных художественных образовательных программах становится фундаментальной предпосылкой профессионального становления и признания. Помимо постоянных и значительных инвестиций в свое обучение, социологическое исследование также выявило ненадежность (шаткость) жизненных траекторий мигрантов, занятых в сфере искусств, а также отсутствие социальных структур, способствующих их выходу на португальский рынок труда.

Ключевые слова: миграция; люди искусства; биографические траектории; формальное обучение; неформальное обучение; Португалия; иммигранты из стран, не входящих в Европейский Союз

* С Ферро Л., Абрантеш П., Велосо Л., Ж. Тейшера Лопеш, 2018. 